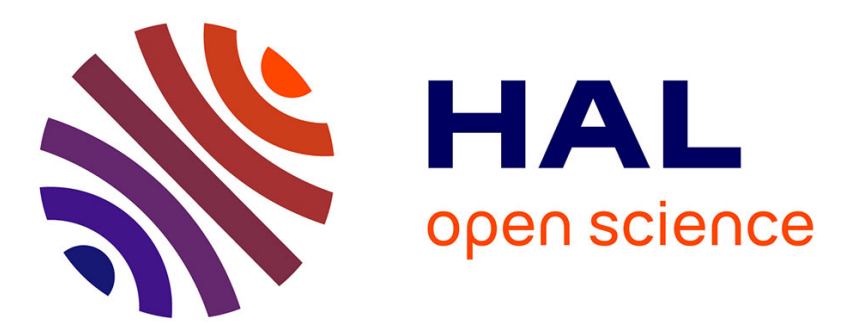

\title{
Unravelling the Experience of Consultants at Work: a Pattern of Role Enactment Beyond Compliance
}

\author{
Lucie Noury, Sébastien Gand, Jean-Claude Sardas
}

\section{To cite this version:}

Lucie Noury, Sébastien Gand, Jean-Claude Sardas. Unravelling the Experience of Consultants at Work: a Pattern of Role Enactment Beyond Compliance. 74th Annual Meeting of the Academy of Management, Aug 2014, Philadelphia, United States. hal-01083892

\section{HAL Id: hal-01083892 https://hal.science/hal-01083892}

Submitted on 18 Nov 2014

HAL is a multi-disciplinary open access archive for the deposit and dissemination of scientific research documents, whether they are published or not. The documents may come from teaching and research institutions in France or abroad, or from public or private research centers.
L'archive ouverte pluridisciplinaire HAL, est destinée au dépôt et à la diffusion de documents scientifiques de niveau recherche, publiés ou non, émanant des établissements d'enseignement et de recherche français ou étrangers, des laboratoires publics ou privés. 


\title{
Unravelling the Experience of Consultants at Work: a Pattern of Role Enactment Beyond Compliance
}

Lucie Noury, Sébastien Gand, Jean-Claude Sardas, Mines ParisTech

\begin{abstract}
In this paper, we contribute to the study of the experience of consultants at work in two ways. First, we develop a framework of role analysis by identifying two core dimensions of consultants' professional role expectations in the literature: knowledge, whether technical or relational, and commitment, both in terms of behaviour and endurance. Second, we go on to apply this framework to 26 interviews of consultants and former consultants, from junior consultant to partner, working or having worked for 15 different firms, in order to better understand how they enact their role along all its dimensions and how it evolves over time. It allows us to spot two different patterns of role enactment: complying and negotiating and to understand their evolutions. Our findings shed light on the heterogeneity of consultants' behaviour, beyond compliance, and allow us to discuss the possibility of resistance in such elite environments.
\end{abstract}

Keywords: professional service firms, management consultants, role enactment, resistance, compliance 


\section{INTRODUCTION}

Although there has been some debate regarding the potential shift of some professional service firms from a traditional professional partnership model (Greenwood, Hinings, \& Brown, 1990) towards a Managed Professional Business once (Hinings, Greenwood, \& Cooper, 1999), the literature still overemphasises the homogeneity of such organisations. Recent studies have however insisted on the existence of different forms of organizing between professions due to differences in knowledge, jurisdictional control and client relationships (Malhotra \& Morris, 2009) or in their degree of professional service intensity (Kipping \& Kirkpatrick, 2012; Von Nordenflycht, 2010). Consulting, in particular, as a weaker profession (Kipping \& Kirkpatrick, 2012), is thought to have the potential to be more diverse in terms of organisational forms. However, this heterogeneity has only begun to be highlighted at professional and organisational levels and the hypothesis that professionals all comply with the expectations the promotion system relies on, at an individual level, remains unquestioned. Most studies of the experience of professionals at work have indeed taken an identity-based perspective and have argued that professionals in general, and consultants in particular, typically do not engage in protest, sabotage nor other forms of resistance to the prescribed subjectivity and that when they do resist, it is only in interrupted ways and resisted by counter-resistance (Kärreman \& Alvesson, 2009). This literature depicts a very compliant professional, which is attributed to processes of identification taking place very quickly and these firms often offering attractive identities based on conformity, elitism and subordination (Alvesson \& Empson, 2008; Alvesson \& Robertson, 2006; Kärreman \& Alvesson, 2009). Not only do such approaches over-emphasise the homogeneous nature of professionals' compliance, but they also solely focus on identity to account for the experience of professionals at work. However, recent studies have highlighted the role played by complementary dimensions such as "body action roles" (Michel 2011) in the way 
professionals respond to their firms' expectations of excellence. Such findings, we argue, introduce the idea that not all professionals may be ready to make the same sacrifices, in particular regarding their health and private lives, in the hope of being promoted, and call for further investigations.

In line with a recent call for further research on the experience of consultants at work (Sturdy, 2012), we argue that, in order to explore further the way professionals handle expectations of excellence and high quality service, there is a need to take on a role perspective instead of a purely identity-focused one and to take into consideration all dimensions of professional role

simultaneously, which includes yet is not restricted to identity. This paper unfolds as follows: we start by drawing on role theory to show that focusing on role enactment can be particularly fruitful to understand the experience of consulting in particular and professional work in general. We go on to review the literature on consulting professionals' role to propose a framework of analysis of role enactment in consulting firms with two core dimensions: knowledge, whether technical or relational, and commitment, which has behavioural and physical correlates. We then move on to detail our methodology before describing the two patterns of role enactment we have identified: complying and negotiating as well as the way they evolve over time. We finally discuss our findings in the light of the literature, which describes consultants as homogeneously compliant and consulting firms as places where little resistance can occur.

\title{
TOWARDS AN ENRICHED FRAMEWORK OF ROLE
}

\begin{abstract}
ANALYSIS
Studies of the lived experience of consultants at work have often taken an identity-based perspective to investigate the interplay between social discourses of elitism and self-identity. Identity theory argues that, in organisations, subjectivities are shaped by practices of identity
\end{abstract}


regulation through both technocratic and socio-ideological controls which have a direct impact on processes of identity construction (Alvesson \& Willmott, 2002). In consulting firms, technocratic controls are most salient in the formal hierarchy, a system of permanent evaluation and formalised career paths. However, socio-ideological modes of control - in other words the regulation of ideas, beliefs, values and identities - are most prominent, and are implemented through socialisation, whether it is during induction seminars, training sessions or other "socio-integrative" events (Alvesson, 1995; Ibarra, 1999; Poulter \& Land, 2008), the construction of elite distinct organisational identities (Alvesson \& Empson, 2008; Alvesson \& Robertson, 2006) and subjectifying practices (Alvesson \& Willmott, 2002; Armbrüster, 2004), which in turn promote self-discipline and contribute to the attraction and retention of individuals. In this environment, processes of identification are thought to take place particularly quickly due to the attractive identities based on conformity, elitism and subordination these firms offer (Alvesson \& Empson, 2008; Alvesson \& Robertson, 2006; Kärreman \& Alvesson, 2009).

Although it emphasises the role played by control, this literature also considers individuals not to be passive and rather engaged in identity work (Watson, 2008). Watson defines identity work as the processes through which individuals try to shape a coherent and distinctive sense of their personal self-identity, which they do by incorporating chosen elements of socially available identities, themselves informed by a multiplicity of social discourses. He also explains that, through identity work, individuals have some scope to re-interpret and change the role given to them within a given social setting.

However, although identity work studies go beyond the subjectifying lens of identity regulation by recognising people's active role in shaping their own personal identity, they seem to overemphasise the exclusivity of the role played by discursive mechanisms in accounting for the way people respond to normative expectations and, as Gill (2013) notes, 
rarely explore the lived experience of individuals. In addition, recent studies have highlighted the role played by other non-discursive dimensions such as "body action roles" (Michel, 2011) for example, in the way individuals handle expectations of excellence and highcommitment.

As a result, there is a strong need to go beyond an understanding of the way professionals respond to normative expectations exclusively in terms of identity work. We argue that taking a role-based perspective will allow us to explore what is going on at the interface between expectations and enactment. Role theory has been abandoned in favour of identity perspectives because of the diversity of approaches it includes and the sometimes contradictory vocabulary it employs (Biddle, 1986) and its tendency to be used in fixed ways, with a lack of critical engagement regarding the political construction of such roles (Simpson \& Carroll, 2008). Role theory has indeed given birth to a wide range of contrasted perspectives from functional approaches seeking to account for conformity and considering roles as shared sets of normative expectations; to structural approaches which rather focus on social structures sharing the same patterned behaviour; or the symbolic interactionist approach which looks at how roles evolve through role taking; the organisational approach which associates roles with identified social positions generated by normative expectations and particularly look at role conflict, role overload and role transitions; or the cognitive approach which explores how expectations impact social conduct (Biddle, 1986). However, not only is the concept still referred to by organisational actors (Simpson \& Carroll, 2008), but it is also still very powerful to examine how normative expectations and individuals' behaviour interact. As a result, many studies today refer to the notion of role in an informal way, without defining it theoretically.

This is precisely why there have been several attempts to reconcile these perspectives by highlighting how they can complement each other instead of conceiving them as contradictory 
(Bechky, 2006; Lynch, 2007). Biddle (1986) notes some convergence towards the understanding that role expectations, in other words scripts for social conduct, are formed in response to the experience of actors and that, in return, characteristic patterns of behaviour emerge. Handle also argues that both perspectives address issues that, far from contradictory, are compatible with the model of the other since structural-functionalist approaches are concerned with the patterning of expectations while interactionist ones focus on the orientation of actors confronted to these expectations (Handel, 1979). As a consequence, Becky (2006) argues that both approaches can be reconciled by adopting a negotiated social order perspective on roles (Strauss, 1978; Strauss, Schatzman, Ehrlich, \& Bucher, 1963), in other words considering the interplay of structural context, role structure and role enactment, the same way integrated order theory considers the interplay of structure, rules and working arrangements. Although role expectations can be seen as widely shared within a specific social system, they remain individually held, which leaves actors some resources for negotiating this role, in other words for enacting it (Bechky, 2006), which is precisely what we want to focus on here.

In addition, to address claims regarding the fixed nature of role theory, other authors have also shown that, when conceived as a boundary object, role can be seen an intermediary device constantly translating meanings between actors and as such playing an important part in identity construction processes, alongside with discourses (Simpson \& Carroll, 2008). As such, they define roles as in constant emergence themselves. Kunda (1992) draws on Goffman's interactionist approach to describe roles as feeding people with information regarding the prescribed subjectivity and, as such, is a source of identity work alongside discourse, ideologies and social identities (Sveningsson \& Alvesson, 2003). We would however go further by arguing that if roles contribute to processes of identity building, identity work is only one of the dimensions of individuals' response to the prescriptions 
associated to their role. The interest of such an approach is its ability to shed light on a comprehensive set of dimensions core to understanding individual experiences at work, which include but are not restricted to their sense of identity and belonging, by taking simultaneously into account, for example, the strategic resources individuals have to face expectations, their physiological resistance, their cognitive ability to do what they are asked and their subjective perception of role expectations (Sardas, 2008; Sardas, Dalmasso, \& Lefebvre, 2011; Sardas \& Gand, 2011). The role approach will allow us to gather insights into how expectations shape individual behaviour but also into how role enactment can question and shape the organisation in return.

\section{ON THE ROLE OF CONSULTING PROFESSIONALS}

Very few studies of professional service firms specifically use role vocabulary, with some notable exception such as the work of Ibarra (1999) to describe what is expected of professionals and how they respond to these demands during role transitions and the work of Pratt, Rockmann, and Kaufmann (2006) who, although they argue they don't take a role perspective strictly speaking, use the concepts of role and role modelling in order to describe how professional identities are constructed among medical residents. The literature has nonetheless shed light on two complementary dimensions of consultants' role: knowledge, whether it is esoteric or relational, and commitment, which has some behavioural and endurance correlates.

\section{Knowledge}

As mentioned earlier, knowledge intensity is one of the core characteristics of professional service work (Von Nordenflycht, 2010) and expertise is said to be the primary value of individuals in the eyes of their firms (Empson, 2001). There has been some debate regarding 
the nature of this knowledge ${ }^{1}$, but some recurrence can be observed in the distinction between "technical knowledge" (whether it is esoteric or more experiential) and "relational knowledge", which involves client and process knowledge as well as what some authors refer to as "socio-political skills" (Alvesson \& Johansson, 2002; Bloomfield \& Danieli, 1995).

\section{Technical knowledge}

Although the role played by consultants in the creation and dissemination of knowledge and management fashion has been the object of many studies (see Canato and Giangreco (2011) for a review), there is less insight into the way individual consultants take part in these processes and what their perceptions are. In traditional professions, such as law or accounting for example, individuals are expected to have a formal knowledge base, often assessed through certification (Abbott, 1988). Consulting being a "weaker" profession (Kipping \& Kirkpatrick, 2012), it is characterised by a less formal body of knowledge. Instead, the knowledge base tends to be more organisation-specific (Morris \& Empson, 1998) and consists in methods and tools developed by the firm (Werr, 2002; Werr \& Stjernberg, 2003). Such methods and tools provide consultants with a formalised description of the sequence of activities, which should guide them in their projects. Werr and Stjernberg (2003) explain how knowing the method and keeping up-to-date on it is an implicit requirement for consultants. Young graduates are recruited and progressively become familiar with these methods and how to mobilise them thanks to initial training and by progressing along the hierarchy (Maister, 1993). Typically, junior recruits start by providing research support to the teams

\footnotetext{
${ }^{1}$ In particular after early functionalist accounts of professional service work were criticised for using the term in a broad sense without questioning the existence of such knowledge nor how it was created, used, maintained and developed (Alvesson 1993, Werr 2002). Typologies were developed, which distinguished for example between information, experience and disposition (Lowendahl, Revang et al. 2001) ; methods, cases and experience (Werr 2002, Werr and Stjernberg 2003); technical expertise and experience or process expertise (McKenna 2006), technical and socio-political skills (Bloomfield and Danieli 1995), or technical and client knowledge (Morris and Empson 1998, Empson 2001).
} 
before they get directly involved in project work and progressively take on more client-facing roles, under the supervision and guidance of their manager, partners approving all deliverables before they get transmitted to the client (Maister, 1993). We can note here that this would not be true in more "grey hair" type of organisations where consultants would already be experienced when recruited and operate as a more or less independent group of peers. This is however not the type of organisations this paper focuses on.

Yet, this type of formal knowledge appears to be used as a guide for action and consultants' daily work seems to be much more experiential (Løwendahl, Revang, \& Fosstenløkken, 2001; McKenna, 2006; Werr, 2002; Werr \& Stjernberg, 2003). Consultants need to be able to use their judgement to adapt this method to local client needs and specificities and deliver high quality service (Morris \& Empson, 1998; Werr, 2002; Werr \& Stjernberg, 2003). To do so, consultants use cases, which are documents produced on other similar projects that can be used as models, and mobilise their own experience and that of others, mostly through face-toface interaction, in order to elaborate a solution tailored to the specific local context (Werr, 2002; Werr \& Stjernberg, 2003; Werr, Stjernberg, \& Docherty, 1997).

Finally, consultants are also expected to feed their experience back into their organisation by sharing it with others and contributing to the improvement of methods, no matter how junior they might be, in spite of the numerous impediments to this knowledge sharing and in particular the fact that their specific knowledge is what makes their firms need them and the fact that such knowledge is highly experiential and not always easy to codify (Empson, 2001; Morris, 2001; Morris \& Empson, 1998; Swart \& Kinnie, 2003; Werr, 2002; Werr \& Stjernberg, 2003). Empson (2001), in particular, has shown how, during mergers, subjective aspects such as the fear of exploitation and contamination can come in the way of knowledge sharing. 


\section{Relational knowledge}

This approach of professional work as mainly involving technical knowledge, no matter how experiential, has been questioned for putting too much emphasis on the knowledgeintensiveness of such services (Alvesson, 1993). This critical perspective has led to emphasise the more relational or "socio-political" (Alvesson \& Johansson, 2002; Bloomfield \& Danieli, 1995) side of consulting work. It involves developing knowledge of the client, the specific functioning of their organisations and the issues they are facing, and building relationships with key individuals Other authors have argued that beyond the knowledge of individual clients, consultants accumulate industry or sector specific knowledge in interaction with these clients (Fincham, Clark, Handley, \& Sturdy, 2008). Such knowledge, when combined with more technical forms of knowledge, contributes to legitimising consultants in the eyes of clients.

In parallel, the nature of the work being intangible and particularly difficult to assess, clients often evaluate consultants on a daily basis, by focusing on signals of their expertise and professionalism (Kitay \& Wright, 2002; Starbuck, 1992). As a result, consultants need to actively manage the interaction process in order to convince clients of the quality of their work, maintain their reputation and that of their firm and secure future work. To do so, consultants need to constantly provide clients with enough reassurance so that they are happy with the service while reinforcing ambiguity to ensure their help will remain needed (Sturdy, 1997). It requires the use of "socio-political" or "rhetorical" knowledge enabling consultants to communicate, persuade clients, do sales pitches and win contracts (Alvesson \& Johansson, 2002; Bloomfield \& Danieli, 1995; Legge, 2002). There is also a need for consultants to preserve the knowledge-intensive image of their service, which leads them to orchestrate the rhetoric around the techniques they mobilise (Fincham, 2002) and to act in a politically sensitive way in order to generate an overall impression of high quality service (Alvesson, 
2001). This is referred to by Clark (1995) as impressions management and implies that consultants learn to play scripts and improvise to convey an image of professionalism.

These critical accounts of the relational dimension of consulting work, although they do provide a lot of insights into how consultants persuade clients of their expertise, however rarely investigate the perceptions and subjective experience of individuals and rather question the relevance of the service they provide.

\section{Commitment}

The need for professionals to master relational knowledge in order to convince clients of the quality of their service and of the existence of their technical knowledge (no matter how genuine it may be) cannot but be complemented by a strong commitment to the "act" of consulting. It implies that consultants are expected to behave "professionally" and have the psychological and physiological ability to sustain this performance in the long term.

\section{Behaviour}

Given the "image-intensity" of knowledge work (Alvesson, 1993), not only do consultants need to learn how to manage the interaction process, but they also need to conform to a specific behaviour, which conveys an impression of professionalism and high quality. A strong emphasis is put on appearing hardworking, impersonal, objective, standardised, predictable and reliable (Alvesson, 2001). In particular, professionals need to be highly committed, which they define as a constant availability, in particular for last minute business trips, and the willingness to work very long hours (Kärreman \& Alvesson, 2009; Kunda, 1992; Meriläinen, Tiernari, Thomas, \& Davies, 2004). In an attempt to implement a system allowing consultants to take predictable time off one night a week at the BCG, Perlow (2012) shows how unimaginable it was for consultants that such a system would work. The 
imperative to work long hours and remain accessible seems to be widely accepted as part of the job. Meriläinen et al. (2004) and Mazmanian, Orlikowski, and Yates (2011) show how professionals actually submit themselves to a self-reinforced norm of permanent accessibility by answering emails on their smartphones outside of work, which provides them with a sense of greater flexibility although it decreases their autonomy, lowers their ability to have breaks from work and as a result increases their stress. Muhr, Pedersen, and Alvesson (2013) also show, for example, how consultants' fantasies about off work activities actually reinforce their desires towards work by maintaining an illusion that they are more than just about work. Consultants are expected to be willing to subordinate to hierarchy, standards and schedules as well (Kärreman \& Alvesson, 2009), which Meriläinen et al. (2004) refer to as the "rules of the game". It implies, for example, accepting staffing decisions no matter what the project they are assigned to is, accepting the evaluation system, decisions made on projects by partners or project managers, or having to stay late to finish a deliverable. Consultants also need to dedicate time outside of projects to the development of their own firm, which involves taking

part in sales proposals, recruitment, training, the organisation of interval events, etc. (Alvesson, 2004).

In such high performance environments, there is in sum an implicit requirement for individuals to exploit their own selves in order to improve constantly at all levels (Alvesson \& Kärreman, 2007; Brunel, 2008; Kärreman \& Alvesson, 2004; Muhr et al., 2013).

\section{Endurance}

If such behavioural expectations and the socio-ideological and technocratic forms of control they rely on target the mind of individuals (Alvesson \& Willmott, 2002; Kärreman \& Alvesson, 2004), recent studies have shown that this isn't without any psychological nor physical consequences. High demands and workloads characteristic of knowledge intensive 
environments can be the trigger of both physiological and emotional fatigue (Barnes \& Van Dyne, 2009; Michel, 2011), burn-out or depression (Mazmanian et al., 2011) since these modes of control directly target the body (Michel 2011). As a result, Pedersen (2008) has shown that consultants are expected to learn to set the limit between the constant exploitation of the self and breaking down. It results in an emphasis on endurance as an additional key element in the performance of professionals (Kosmala \& Herrbach, 2006). To sustain such a level of commitment over time, Michel (2011) has shown how professionals initially develop a "body as object" action role, which means that they actively and successfully control their body, before they take on a "body as antagonist" action role, which means that the body usually takes over. She finally describes how some professionals $(40 \%$ of the bankers she followed), after a few years, manage take on a "body as subject" action role, which means that they listen to their bodies more and stop trying to master them, which she says results in increased performance and creativity.

Although some insightful look at both knowledge and identity (see for example Alvesson and Empson (2008); Empson (2001); Kärreman and Alvesson (2009)) or identity and endurance (see for example Michel (2011) or Muhr et al. (2013)), very little studies look at both technical and relational knowledge together with commitment and endurance. We suggest taking an integrated approach to investigate the following question: how do consultants enact their role along all its dimensions?

Insert Table 1 about here 


\section{METHODS}

\section{Research participants}

Given the exploratory nature of our research question, the choice was made to interview consultants working for firms with different expertise claims, including the formalised methodologies and tools of strategy consultants, the technical expertise necessary to financial consultants or the more blurry set of knowledge claimed by management consulting firms. 25 consultants were interviewed from junior consultant to partner, working or having worked for 15 different firms. We also interviewed three former consultants to better understand what had led them to leave the industry. The sample was constituted as follows: initial contacts were made with consultants one of the authors knew, who then referred the research team to other consultants they had not met before; other participants were also contacted as alumni of the institution the first author graduated from and, finally, some of the consultants were also referred by some of the HR directors who accepted to take part in the study. All interviews took place within French consultancies or French subsidiaries of multinational consulting firms.

\section{Data collection}

A life history approach (Bertaux, 1981), with a focus on work and career, was adopted in order to grasp consultants' initial motivations, their perception of what has been expected from them all along their career, how they have responded to it and how it has evolved over time. Considering that only individuals can establish subjective links between their past experiences, their interpretations and their aspirations for the future (Bertaux, 1981), life history interviews were most appropriate to gain insights into what consultants themselves define as important professional or personal standpoints in the way they have enacted their role all along their careers. Interviews were rather open: participants were typically asked to tell their story starting from higher education and later probed, when necessary, to explore 
further themes around knowledge, client relationships, business development, evaluation, promotion or work-life balance for example.

Interviews took place between April and June 2011 and lasted between 30 and 105 minutes, with an average of 75 minutes. Extensive notes were taken and interviews were systematically transcribed verbatim within 24 hours of the interview.

\section{Data analysis}

Consultants' histories were then gathered to constitute a set of individual case studies that we later aggregated in line with the patterns (Yin, 2009) of role enactment that we could spot after coding our data along the dimensions of the analytical framework presented above. Two distinct patterns of role enactment were then identified, as well as the way they appeared to evolve over time.

\section{FINDINGS}

\section{Two different processes of role enactment}

Complying

The first pattern of role enactment we have identified is in line with what has been previously described by the literature as "compliance". 15 consultants displayed behaviour characteristic of this type of role enactment. What is core to the way they enact their role is not their will to develop knowledge but rather their strong identification with the ideal consultant and their will to progress up the hierarchy of the firm quickly. They frequently have a negative vision of experts and say they chose consulting specifically because they did not want to specialise too early on:

“Maintaining your expertise means becoming fossilised. (...) You can't remain an expert for twenty years.

Some things are stable but the technology evolves. I define myself as someone who can have a certain level of expertise quickly. And I think I'm good at it!' (William, ex Manager) 


\title{
Working Paper - Confidential
}

\begin{abstract}
"Everyone is smart, but not everyone has a strategic vision. Some people are good experts for example. But we are evaluated on all these dimensions. You never get there, it requires a certain spirit because you could think: "that's it, I'm really good at this", but there's always something you must make progress on. It's impossible to rest in consulting. " (Eva, Senior Manager)
\end{abstract}

They think experts don't evolve, are stuck in their ways. They believe that their job is more to adapt to clients' local situations and have an ability to quickly know how to solve a problem, rather than offer what they consider to be a fixed, quickly out of date, expertise. They value their ability to handle client relationships and take part in business development, which they consider to be the proof that their firm trusts them, like Helen:

"I don't like what is repetitive. When you are a junior consultant you know you need to produce. But what I like is the contact with clients, interviews, the trust I'm given: being alone with clients. And in the end there is a kind of pressure that I enjoy, it makes me productive." (Helen, Junior Consultant)

As a result, a very high degree of compliance to role expectations is notable in their discourse and in the behaviour they describe. They project themselves within the firm, sometimes all the way to partnership, and no other role matters as much in their life as their professional role:

"The more I practice consulting, the more I think I can do that all my life. I get a lot out of it, I mean, considering the variety of topics I work on. I don't think there is no other job that can be so rich: the environment, people you talk to... (...) It still stimulates me, intellectually speaking. I want to succeed even more." (Eva, Senior Manager)

"I have two kids, and I'm about to have a third one. There have been times when I hardly saw my children, although the only thing I care about is them. (...) I have no problem not seeing them several weeks in a raw. But I would have a big problem having a career that goes nowhere. (...) It's not a job you do if you're looking for comfort. It's the perspective of comfort that matters! (...) It's worth giving it all now, I'd rather suffer now and enjoy later. I'd rather start by going up than down." (Henry, 
It is interesting to see that the discourse of these consultants is often dominated by the idea of a better future, worth chasing. Whether it is a promotion allowing them to choose their projects in the future, having more autonomy, a valuable experience or even more money, they live in the constant promise of a reward. They do not count hours, remain accessible no matter what because they believe it is part of their role as a consultant and agree to subordinate to a number of decisions concerning their staffing and their career. They also explain that although the workload is generally heavy in consulting, they could very well work less but actively choose to do so because they want to be the best at what they do and hand in deliverables of high quality, which they often relate to being promoted:

“The workload wasn't imposed on me. I was imposing it to myself. I was working a lot, probably too much. For my Carmaker project, I got there in the morning at 8am, I usually left at 8pm and only had a sandwich for lunch. I was very committed to what I was doing. " (Anna, ex Manager)

"I have worked a lot. More than others. So I progressed quickly. I went beyond my limits. I thought it was better to give it all I because honestly it makes no difference whether you're leaving work at 5 am or at $11 \mathrm{pm}$. The night is over anyway. (...) I was buying myself a sort of tranquillity by working more than was asked of me. “ (Henry, Director)

Not only do they put a lot of effort into their projects, but they also take part in many internal projects (organising seminars, training sessions, recruitment...) as well as in business development (proposals, development of new offers, etc.). When they overcome challenges (working on a complex project, with a difficult client, around tight deadlines for example), they often refer to the "adrenaline" it generates, the sensation of being "high" that it provides. As a result, work often comes in the way of their private life and they believe this is the price to pay to be able to have such a fulfilling job: 


\section{Working Paper - Confidential}

"You work at night, a bit on week ends, but the job requires it. I take it as something inevitable. I think it's the price to pay if you want responsibilities and some interest in what you do. You have to make concessions, and it's often regarding your private life." (Kate, Manager)

However, although they subordinate to a number of decisions regarding their staffing and their career, they do not do so passively. For example, they appear to have developed specific strategies to gain some control over staffing decisions and ensure they can work on the projects they like, with the appropriate level of "stretch" and with people they appreciate. That's why they explain developing "acquaintance" strategies, which implies building strong relationships with some key partners they like and who value their work so that they defend their performance in evaluation committees. They also develop "reputation building" strategies, which imply making sure people talk about them and their work positively so that even people who have never worked with them have a good image their work, know what their aspirations are and think of them when an interesting project comes up.

“There's no order in which you learn, it is very project dependent. I don't feel like I am not in control but I have always accepted to be assigned projects I didn't choose. But that's where networks come in.

You need to advertise yourself in the firm. I've always had the projects I wanted in the end. I have managed to anticipate and leave projects when needed, to discuss with managers in the hallway... And also, if you make the effort to contribute to proposals, there are a lot of chances you will work on this project afterwards. People enjoy working with people they know, so you need to know everyone! I had another strategy that was to take part in internal projects. I was organising conferences, trainings, seminars. On the side of projects, I have always been involved in the life of the firm. So if you are proactive you can be in control." (Eva, Senior Manager)

Considering all the effort they put in, these consultants often have difficulties handling failure and want to be excellent all the time. Liz, for example, a young manager, kept taking more and more responsibilities while she was pregnant because she wanted to show it wouldn't 


\section{Working Paper - Confidential}

change anything about how committed she was and to prove how badly she wanted to be promoted:

"I was pregnant during one of my projects. Everything was fine, I was even given more responsibilities. Even my client was asking if I was sure about it, he thought it would be horrible for me. But I said yes, and everything went perfectly well. I took my maternity leave one month before the evaluation committee, with three weeks less than other consultants. But I mean, I had had very complex responsibilities, I hadn't gotten any rest at all! I had real hopes for this committee." (Liz, Manager)

As a result, they have a tendency to hide problems, afraid that it may impact their careers. Victor, for example, explains how he was left alone on a project where he did not understand what he was supposed to do nor the demands of the client. He explains he didn't ask for help because he thought he had to succeed on his own. Daniel, another junior consultant, explains how when he suffered a burnout he lied to his colleagues and said he had mononucleosis so they wouldn't think he was weak.

"I don't like asking for help. (...) On top of it I had been told that I had been given that project precisely because I had the right profile, they said "if we throw you in the middle of the pool, you always manage to get back to the border". So I was crying in the morning before going to work... That wasn't normal but I was in denial. I thought I had to succeed.” (Victor, Senior Consultant)

"I lied. I said I had mononucleosis because I would have been done. Unfortunately, if I had told them it was a burn out, it would have been like "ok, he's not resistant enough, it's over for him." (Daniel,

Junior Consultant)

As a result, they go on to either actively develop strategies to submit their bodies and some of them even completely deny the impact such "body roles" can have on their health. Henry, for example, explains how he controls his sleep so he can work longer hours, uses holidays to 
gain energy while feeling that he is making a physical investment in his career and Amy explains how she completely denied her health:

"I know I have the capacity to get very little sleep for some time. If I go to bed at 5am three times in a row and then I sleep normally for two nights, I'll be fine. (...) You need to know yourself, know your rhythm, the one you can sustain in the long run. And it's discipline as well. During holidays I make sure I do some sports, I try to regain a maximum of energy. Are there any consequences of this lifestyle? Well, I have intercostal pain, I used to smoke a lot too. I've had problems with my ligaments as well. But it's a choice. It depends how you want to invest your physical capital. The physical stuff you can manage. It's not a problem." (Henry, Director)

"I worked a lot, and very regularly I had like mini burn-outs, like mini breakdowns. So I took a few days off, took some medicine, and worked even more afterwards. I didn't question anything." (Amy, ex Manager)

Negotiating

The second pattern of role enactment that was spotted was labelled "negotiating" because the consultants who displayed such behaviours seemed to choose which expectations to meet as well as the means employed to do so. 15 consultants did so at some point in their careers. They either joined consulting because they wanted to develop a specific expertise (whether it was expertise in a specific field or industry) or quickly discovered an interest in a particular area or in project work in general. The major difference with compliant consultants is that what they are very enthusiastic about isn't the positive outcome of their evaluations although it obviously matters to them as well - but rather the content of what they do, which they consider to be a reward in itself. As a result, although they also develop staffing strategies, what matters to them is to gain control over what they will learn and how much they will enjoy the project. Similarly, they are happy to negotiate their sales objectives so that they get to work on the projects that they like. James, for example, explains how he 
deliberately chooses to take some exciting contracts that are not good for him in terms of sales objectives even if that means taking on another, bigger, better paid project to compensate:

"Me, for example, I rationally choose some contracts that are no good for me, in terms of volume or billing rate. But it's like a treat to me! There are some strategies of, let's say, meal composition... A Junior consultant will have less ability to do this though." (James, Director)

The notion of service is also particularly emphasised: they believe it is core to what they do and that they have the ability to make a difference, even if they say that not all consultants serve their clients the way they think they should. In order to make sure that the service they provide is of quality, they also negotiate with clients to make sure the scope of projects and their budget will allow the team to deliver quality work within the time frame. Even very junior consultants can do so by discussing day-to-day tasks with clients, as Sylvia explains:

"There are two types of people. Those who enjoy that you're not all about work, and those for whom you need to work, work, work. Very often, the contract doesn't say much about what we're supposed to do so we don't really know and the client either. So all along the project, the partner needs to define what we do or don't do, what would be a different project, require other resources. But some partners say yes to everything! It happens all the time, even at my level. Clients ask for stuff and you need to say no or to say that you will see if there's enough time. There's a category of people who have a life, a wife and have the courage to say no because they don't want to sacrifice everything and don 't ask it of their teams." (Sylvia, Senior Consultant)

They identify with the category of consultant but other roles often matter as much to them, such as being a parent or having a specific hobby. Karen, for example, had decided when she was still a junior consultant that she would take acting classes, which meant she had to leave at 6:30pm twice a week every week. For Sylvia, it is important that she can go to Spain visit her family once a month and that she has time to go to the gym:

"I like to go to the gym in the morning. So I don't get to the office before 9:30am. It's my thing, I need it. I always tell the team when I start a project, this way, if it doesn't work for them, we can find 


\section{Working Paper - Confidential}

solutions. If it's better I go in the evening. But in that case, I have to be able to go! Cause the reason I go in the morning is that I tried to go in the evening but it didn't work. There was always something coming up at the last minute." (Sylvia, Senior Consultant)

This reinforces the way they negotiate with clients, because not only do they want to make sure the quality of assignments can be ensured, but they also want to make sure a balance can be maintained. It also implies negotiating with project managers or partners whenever needed, as Lauren told us:

"You need to know your limits and make sure people accept it. You need to send partners back to their responsibilities. There is this image of consultants being pressurised without having a say in it, but there's a real risk that people will break down and leave. There's a need to think about long term wellbeing, to manage it, in the interest of clients. There can always be some last minute emergencies, but in that case you need to negotiate the perimeter. Do the minimum. We have high profile people who enjoy to do things well, so it's difficult. We need to define the perimeter of what we work on." (Lauren,

Partner)

Some other consultants find ways to adapt their working hours so they can pick up their children from school and spend time with them. For such negotiation to succeed, they need to make some compromise. Emily, for example, who worked part time when her son was little, it implies remaining flexible:

"The difference between working full-time and working half-time is so big that partners need to take it into account. But on the other side I remained very flexible. Since you report on your working hours to bill clients, it's easy to see when you've worked too much and you get it back the following week. If you looked at the whole year, overall, it was half-time." (Emily, Director)

"You have to remain flexible, that's what you're paid for. You have to make effort. But for it to remain sustainable, you need to have some things you're not ready to give up. For example on Thursday nights, when I come back from work, I don't work. Even if I'm not done, it will wait for Friday morning. This way I know I can spend time with my boyfriend, meet some friends. Work will wait. On Mondays, I 


\section{Working Paper - Confidential}

know I usually work til midnight, because on Fridays I'm at the office and there are always people to see and things to do, and I want to preserve my week end, so I know on Mondays I have to make some effort. When I'm on a business trip, I work constantly. Of course I would prefer to watch a movie in my hotel room, but I don't do it because it's time my boyfriend or my friends won't benefit from. But I'm not French, and I go visit my family once a month, or they come over. You take that from me once, ok, but you take it from me twice and I quit." (Sylvia, Senior Consultant)

For others, it is implies keeping a low profile, or even accepting a slower career progression:

"Twice a week I had to go to the theatre for rehearsals that started at 7:30pm so that meant I had to leave at 6:30pm twice a week. I had my rehearsals until 10:30 or 11pm. But after that, I didn't mind working again. Everybody knew I worked after. It was quite naïve of me to do that, no one else did it! It was fine, people got used to it. But it wasn't like "I want to preserve my personal time", no... it was like "I wanna do it, I do it and if it doesn't work, I'll stop" (Karen, Manager)

"There were times when I was working really hard. Now I work a little less because I am pregnant and I have other priorities. That's all right. Everyone gets rewarded depending on the effort they put in. I think this is good. If your goal is to have the best raise and to be promoted, then you need to be in the top rankings. But you need to arbitrate; depending on what you want. For example, the first time I was pregnant, they wanted to make me manager, and I said no. I said "No I don't want to become manager now, leave me alone, I don't want more responsibilities now". They respected it, they said they understood I didn't want to take that role at that time. If I had said no eternally there would have been a problem, but saying no once because you have something going on in your life is ok." (Kate, Manager)

Even when they still project themselves all the way to partnership, it seems difficult for these consultants to compete with people who comply more than they do. Sometimes, they say they think they will not be able to sustain the way they enact their role in the long term. Susan, for example, has chosen to work part time to have some flexibility, but still hopes to make it partner one day. She explains how difficult her choice is to sustain: 


\section{Working Paper - Confidential}

"It's hard to be moderate. Working 50\% of the time completely questions the system: 50\% of what?

When I came back from maternity leave at $60 \%$, I could organise myself, it was supposed to work. I'm on two projects maximum or one project and business development on the side. But I sell myself at $60 \%$ on a project that requires $100 \%$ of a project manager. And to be promoted, you need to show you want it, people think you don't cause you're still at 60\%, they think: "she needs to rise”. And we are on a Gauss curve, so I get compared to colleagues who work 90 hours a week, say yes to everything, their wives don't work. I have to say no, so I say no. And the other ones always say yes." (Susan, Director)

As a consequence, they tend to leave more, either for a competitor or even for a client, whenever they believe the balance is no longer sustainable:

"I've always been able to see myself staying for a long time. I can see myself staying... until I'm asked to leave, or until it doesn't fit anymore. I don't know how it will end; I don't think long term. That's how I've managed to stay for so long actually! The day they ask me to do things differently, not necessarily to work more, but differently... I won't fight. I will take my things and go. I will be disappointed, but I will go.” (Karen, Manager)

By protecting some parts of their private lives, such as family times, sport practice, a hobby, they also in turn organise some breaks, some time to regulate their lifestyle, while remaining flexible and committed enough in their opinion. They also seem to pay attention to the signs their body may send them and immediately react by telling their managers they cannot handle the workload or meet the deadline and either negotiate the deadline or some help.

\section{Evolution and outcomes of role enactment over time}

Through consultants' histories, two patterns of role enactment have emerged, which would be best qualified as processes: role enactment is constructed day after day, as opportunities for complying or negotiating occur. Also, although they often seem to remain stable for many consultants, they can evolve over time. First, these two modes of role enactment are not always successful. Outside of consultants who do not perform and are asked more or less 
explicitly to leave, others end up quitting consulting because they do not manage to sustain their mode of role enactment over time. Complying, in particular, seems to be difficult to sustain since 5 consultants out of the 28 ones we met suffered from what they label "burnout", when no negotiating consultant did. Consultants who went through this experience all explain how much their will to overcome challenges and be valued for their effort had led them to put their health at risk and to deny difficulties of any kind. Some other complying consultants also reported feeling frustrated by the slowing down of their career progression after becoming Manager, which led them to question whether they wanted to leave. However, complying consultants were not the only ones to enact their role unsuccessfully. Some negotiating consultants also seemed to have difficulties enacting their role when they were particularly interested in developing expertise in a firm where it was not a priority.

Second, there was also some evidence of consultants switching from complying to negotiating. Indeed, some life events seem to trigger a change in priorities (typically the birth of a child), which leads some consultants whose compliant form of role enactment used to be very successful, to start negotiating more and more to protect that area of their life. During our interview, Eva, for example, was pregnant and started to question whether she would be able to sustain her work life balance after giving birth and whether she would manage to remain visible, and to be assigned strategic projects. Some consultants also appear to switch to negotiating when they haven't been successful at sustaining a complying mode of role enactment over time, typically after a burnout. John, for example, explains particularly well how he went beyond his limits trying to comply with expectations and how his burnout completely changed him. He says he now delegates more, doesn't say yes systematically and selects his assignments so he can work less and have a better work life balance.

It can also be noted here that some consultants refuse to enact their role right from the start. These consultants (three cases in our sample) reject entirely project work, which they see as a 
form of manipulation of clients, consider commitment expectations as "slavery", and want to leave as quickly as they can. They however remain a minority and their choice to join consulting was a mistake in the first place.

\section{DISCUSSION}

\section{Relevance of the comprehensive framework of role analysis}

By looking simultaneously at the knowledge and commitment dimensions of professional role, two patterns of role enactment have emerged: complying and negotiating.

Insert table 2 about here

As a consequence, we argue that the subjective experience of consultants cannot be understood without looking simultaneously at all the dimensions of their professional role. It is their will to face challenges, to be given responsibilities and to progress quickly that leads some consultants to identify very quickly and very strongly with the category of consultants and display a very high level of commitment, while they regard experts as non adaptable and lacking ambition; in turn complying to role expectations. It is also because they are interested in the content of project work more than promotions and because they often have investments outside of work that some other consultants instead negotiate the way they are supposed to enact their role expectations, although they can project themselves within the organisation sometimes even all the way to partnership. As a result, the characteristic behaviour of these consultants with their clients, project teams, as well as their involvement in business 
development and HR processes, and the way they manage their workload and timetable cannot be understood without looking all these dimensions as intertwined.

In addition, our results also shed light on the fact that although consultants are described in the literature as displaying homogeneous - compliant - behaviours; there appears to be more diversity in the way they enact their role. They can have different perceptions of the type knowledge involved in their work, of the nature of their relationships with clients and also of the type of compromise (regarding the projects they are assigned and their time off work) they are willing to make for their careers. They also seem to display both "body as object" and "body as subject" action roles (Michel, 2011), right from the start; which contradicts Michel's finding that all professionals started their career in a "body as object" action role before only $40 \%$ went on to later develop a "body as subject" one.

\section{Negotiating as a form of resistance}

The results presented above have highlighted the fact that some consultants go beyond compliance and negotiate some of the dimensions of the role they are offered in order to accommodate their private lives and their ambitions. Can these individuals be considered to be resisting role expectations, in turn resisting the underlying assumptions of the promotion system?

Research into resistance has emerged after cultural research programmes were questioned for depicting an over-totalizing view of managerial power in organisations (Fleming, 2005) and has aimed at understanding how individuals can fight cultural controls. Such resistance can be collective, through unions or strikes for example, or consist in more daily actions or attitudes such as irony, scepticism, humour or sabotage (Fleming \& Spicer, 2003). For Kärreman and Alvesson (2009), resistance is a process of "adaptation, subversion and reinscription of dominant discourses", which means that all actions that are not in line with the prescribed 
subjectivity can be considered as resistance. As we saw earlier, Kärreman and Alvesson (2009) have argued that there is little resistance in consulting firms and that when a discourse of resistance is perceptible, it is lessened by a discourse of counter-resistance. In such environments, even when individuals experience cynicism they are thought to do so without complying less (Poulter \& Land, 2008). Here, a pattern of role enactment that goes beyond compliance has however been identified: negotiating. It goes beyond the forms of resistance observed by Kärreman and Alvesson (2009) since the discourse of the autonomous and committed professional doesn't seem to operate as counter-resistance and instead makes resistance possible by allowing these consultants to show that they are highly committed even if they do not fully comply. It is only because they say they remain flexible and are willing to make compromise that these consultants manage to sustain their way of enacting their role. As such, negotiating isn't a hostile or adversarial form of resistance but rather is adopted by consultants who do contemplate a career in consulting in the long term and who, in order to make it sustainable, attempt to change the "rules of the game" in a non-vindictive way. This is in line with what Courpasson, Dany, and Clegg (2012) have described as "productive resistance", in other words a form of resistance which can generate positive change for the organisation. Here, resistance is not conceived as adversarial nor hostile but rather as the source of adjustments of role expectations allowing some consultants, who are considered to be performing, to stay.

We have nevertheless also seen how difficult such a form of resistance was to sustain in the long term since most consultants do comply and, in the long term, resisting consultants tend to be considered less performing since their commitment is usually quantitatively inferior to that of compliant consultants. It would however be very interesting to investigate the performance of organizations in which the way negotiating consultants enact their role generates organisational adjustments in terms of role expectations and career paths. 


\section{CONCLUSIONS}

Through the analysis of the work stories of 28 consultants, two patterns of role enactment complying and negotiating - and the way they evolve over time were identified. These findings seem to shed a new light on the up-or-out system. Although some consultants do leave because their performance is poor, many do either because they break down or because they are no longer satisfied with the deal consulting offers them. What matters here is that these consultants are not underperformers but professionals who are pushed towards the exit by a mode of organizing that generates breakdowns and frustrations. In addition, the fact that the majority of consultants comply means that expertise is a smaller driver for consultants' careers than competition. As we saw, compliant consultants often have a negative perception of experts and where permanent non-partner alternative roles had been created - either officially, or in practice - they were perceived negatively, as the failing route taken by consultants who were not good enough to become partners. It is also very hard for negotiating consultants, to whom career isn't a priority, to project themselves in the long term since their quantitative commitment remains inferior to that of compliant consultants. It may suggest that consulting firms reward endurance more than expertise. As such, perhaps it should be described as an "Out or Up" system, in which consultants who manage to stretch, handle heavy workloads in the long run and can take frustration are promoted to senior roles.

This system bares a major risk: eliminating the expertise and experience that are precisely core to the service provided. It should be regarded as all the more problematic that Professional Service Firms have been subject to major changes since the 1980's (Gand, 2008): not only have demands become more and more complex and sophisticated (Powell, Brock, \& Hinings, 1999), but increasing financial pressure on the client side has also led to an 
intensification of competition (Galanter \& Palay, 1992; Malhotra, Morris, \& Hinings, 2006; Matthews, 2006; Powell et al., 1999; Stumpf, Doh, \& Clark, 2002), resulting in professional firms' need for a wider range of expertise (Gadrey, 1994; Malhotra et al., 2006), increased specialisation (Gardner, Morris, \& Anand, 2007) and cost efficiency. With the industry facing such an acceleration of the activity, time dedicated to learning has shrunk considerably, while professional environments have always been characterised as stable and relying on long learning curves (Greenwood et al., 1990; Mintzberg, 1989). However, what our findings suggest is that, in spite of potential alternate roles, there is only one successful way to progress in consulting firms, which is predominantly through high levels of commitment and commercial skills since consultants with a specific interest in service work and outside of work investments either leave or experience difficulties competing with more compliant consultants. The possibility of alternate trajectories, as in science-based environments (Debackere, Buyens, \& Vandenbossche, 1997; Katz, Tushman, \& Allen, 1995), remains an open issue in consulting firms in order to sustain long- term performance and legitimacy. There is also a complementary need to explore further the possibility of alternative forms of organising in professional service firms, allowing the retention negotiating consultants. 
TABLE 1

Summary of professional role dimensions

\begin{tabular}{|c|c|}
\hline \multicolumn{2}{|c|}{ Professional Role Dimensions } \\
\hline Knowledge & Commitment \\
\hline $\begin{array}{l}\text { Technical } \\
\text { - } \quad \text { Know the method and keep } \\
\text { up-to-date } \\
\text { - } \text { Be able to adapt it to local } \\
\text { contexts } \\
\text { - Share your knowledge } \\
\text { (whether esoteric or } \\
\text { experiential) }\end{array}$ & $\begin{array}{l}\text { Behaviour } \\
\text { - } \quad \text { Convey an impression of } \\
\text { professionalism } \\
\text { - } \quad \text { Work long hours and } \\
\text { remain accessible } \\
\text { - Subordinate to hierarchy, } \\
\text { - } \text { standards and schedules } \\
\text { Contribute to the } \\
\text { development of the firm }\end{array}$ \\
\hline $\begin{array}{l}\text { Relational } \\
\text { - Develop Client knowledge } \\
\text { - Manage the interaction } \\
\text { process }\end{array}$ & $\begin{array}{l}\text { Endurance } \\
\text { - Sustain this behaviour in } \\
\text { time }\end{array}$ \\
\hline
\end{tabular}


Working Paper - Confidential

\section{TABLE 2}

Comparative summary of patterns of role enactment among consultants

\begin{tabular}{|c|c|c|}
\hline $\begin{array}{c}\text { Professional role } \\
\text { dimensions }\end{array}$ & Complying & Negotiating \\
\hline \multicolumn{3}{|l|}{ Knowledge } \\
\hline $\begin{array}{l}\text { Technical } \\
\text { Knowledge }\end{array}$ & $\begin{array}{l}\text { Technical knowledge seen as an ability } \\
\text { to adapt very quickly to new topics and } \\
\text { acquire new expertise needed on } \\
\text { projects. } \\
\text { Experts seen as "stuck in their ways". }\end{array}$ & $\begin{array}{l}\text { Technical knowledge seen as a core } \\
\text { component of consultants' performance } \\
\text { and a strong driver in their career. } \\
\text { Staffing strategies to gain control over } \\
\text { the content of the projects they are } \\
\text { assigned and what they will learn. }\end{array}$ \\
\hline $\begin{array}{l}\text { Relational } \\
\text { Knowledge }\end{array}$ & $\begin{array}{l}\text { Relational knowledge considered to } \\
\text { play a critical part in consultants' } \\
\text { performance, especially as it involves } \\
\text { building relationships with clients and } \\
\text { developing future business. } \\
\text { Tendency to accept extra requests from } \\
\text { good clients, which is considered } \\
\text { legitimate. }\end{array}$ & $\begin{array}{l}\text { Emphasis on the service dimension of } \\
\text { relational knowledge. } \\
\text { Attempts to ensure budget and deadlines } \\
\text { allow the team to provide such high } \\
\text { quality service before the project starts, } \\
\text { and when extra requests arise. }\end{array}$ \\
\hline \multicolumn{3}{|l|}{ Commitment } \\
\hline Behaviour & $\begin{array}{l}\text { Strong identification with what they } \\
\text { consider the ideal consultant to be } \\
\text { which results in a high level of } \\
\text { commitment (strong availability, } \\
\text { flexibility, involvement in internal } \\
\text { projects, etc.) in the hope of quick } \\
\text { promotions. } \\
\text { Staffing strategies to gain control } \\
\text { over the evaluation process and } \\
\text { their reputation. }\end{array}$ & $\begin{array}{l}\text { Strong commitments outside of work } \\
\text { (family, hobby, friends etc.) which } \\
\text { result in an increased tendency to } \\
\text { negotiate deadlines and the scope of } \\
\text { projects to ensure work life balance } \\
\text { will be preserved; and implies } \\
\text { working from home and/or adapted } \\
\text { schedules, even if it is at the cost of a } \\
\text { slower career progression. } \\
\text { Only consultants who however } \\
\text { remain flexible can succeed in doing } \\
\text { so. }\end{array}$ \\
\hline Endurance & $\begin{array}{l}\text { The body is considered as the } \\
\text { means to an exceptional } \\
\text { performance. } \\
\text { Difficulty to handle failure and } \\
\text { tendency to hide difficulties. }\end{array}$ & $\begin{array}{l}\text { Preservation of time off work. } \\
\text { Tendency to call for help and/or warn } \\
\text { their superiors when facing a heavy } \\
\text { workload. }\end{array}$ \\
\hline
\end{tabular}




\section{REFERENCES}

Abbott, A. (1988). The system of Professions. Chicago: Chicago University Press.

Alvesson, M. (1993). Organizations as rhetoric: knowledge-intensive firms and the struggle with ambiguity. Journal of Management Studies, 30(6): 997-1015.

Alvesson, M. (1995). Management of Knowledge Intensive Companies. Berlin: Walter de Gruyter.

Alvesson, M. (2001). Knowledge work: Ambiguity, image and identity. Human Relations, 54(7): 863-886.

Alvesson, M. (2004). Knowledge Work and Knowledge-Intensive Firms: OUP Oxford.

Alvesson, M., \& Empson, L. (2008). The construction of organizational identity: Comparative case studies of consulting firms. Scandinavian Journal of Management, 24(1): 1-16.

Alvesson, M., \& Johansson, A.W. (2002). Professionalism and politics in management consultancy work. In T. Clark \& R. Fincham (Eds.), Critical Consulting (pp. 228256). Oxford: Blackwell.

Alvesson, M., \& Kärreman, D. (2007). Unraveling HRM: Identity, Ceremony and Control in a Management Consulting Firm. Organization Science, 18(4): 711-723.

Alvesson, M., \& Robertson, M. (2006). The best and the brightest: The construction, significance and effects of elite identities in consulting firms. Organization, 13(2): 195-224.

Alvesson, M., \& Willmott, H. (2002). Identity Regulation as Organizational Control: Producing the Appropriate Individual. Journal of Management Studies, 39(5): 619644.

Armbrüster, T. (2004). Rationality and its symbols: Signalling effects and subjectification in management consulting. Journal of Management Studies, 41(8): 1247-1269.

Barnes, C.M., \& Van Dyne, L. (2009). I'm tired: Differential effects of physical and emotional fatigue on workload management strategies. Human Relations, 62(1): 5992.

Bechky, B.A. (2006). Gaffers, Gofers, and Grips: Role-Based Coordination in Temporary Organizations. Organization Science, 17(1): 3-21.

Bertaux, D. (1981). Biography and society: life history approach in the social sciences. Beverly Hills, CA: Sage.

Biddle, B.J. (1986). Recent Development in Role Theory. Annual Review of Sociology, 12: $67-92$. 
Bloomfield, P.D., \& Danieli, A. (1995). The Role of Management Consultants in the Development of Information Technology: the Indissoluble Nature of Socio-Political and Technical Skills. Journal of Management Studies, 32(1): 23-46.

Brunel, V. . (2008). Les managers de l'âme : Le développement personnel en entreprise, nouvelle pratique de pouvoir? Paris: Editions la Découverte.

Canato, A., \& Giangreco, A. (2011). Gurus or Wizards? A Review of the Role of Management Consultants. European Management Review, 8: 231-244.

Clark, T. (1995). Managing consultants: consultancy as the management of impressions: Open University Press.

Courpasson, D., Dany, F. , \& Clegg, S. . (2012). Resisters at Work: Generating Productive Resistance in the Workplace. Organization Science, 23(3): 801-819.

Debackere, K., Buyens, D., \& Vandenbossche, T. (1997). Strategic career development for R\&D professionals: lessons from field research. Technovation, 17(2): 53-62.

Empson, L. (2001). Fear of Exploitation and Fear of Contamination: Impediments to Knowledge Transfer in Mergers between Professional Service Firms. Human Relations, 54(7): 839-862.

Fincham, R. (2002). Charisma versus Technique: differentiating the expertise of Management Gurus and Management Consultants. In T. Clark \& R. Fincham (Eds.), Critical Consulting: New Perspectives on the Management Advice Industry: Blackwell Business.

Fincham, R., Clark, T. , Handley, K., \& Sturdy, A. (2008). Configuring expert knowledge: the consultant as sector specialist. Journal of Organizational Behavior, 29: 1145-1160.

Fleming, P. (2005). Metaphors of Resistance. Management Communication Quarterly, 19(1): 45-66.

Fleming, P., \& Spicer, A. (2003). Working at a Cynical Distance: Implications for Power, Subjectivity and Resistance. Organization, 10(1): 157-179.

Gadrey, J. (1994). La modernisation des services professionnels. Rationalisation industrielle ou rationalisation professionnelle? Revue Française de Sociologie: 23-41.

Galanter, M., \& Palay, T. (1992). The Transformation of the Big Law Firm. In R. L. Nelson, D. M. Trubek \& R. L. Solomon (Eds.), Lawyers' Ideals / Lawyers' Practices. Transformations in the American Legal Profession. Ithaca (NY), London: Cornell University Press.

Gand, S. (2008). L'organisation des dynamiques de services professionnels : logique de rationalisation, cadre de gestion et formes de collégialité. Mines ParisTech, Paris. 
Gardner, H. K., Morris, T., \& Anand, N. (2007). Developing new practices: recipes for success. In L. Empson (Ed.), Managing the modern law firm. New challenges, new perspectives. Oxford: Oxford University Press.

Gill, M.J. (2013). Elite identity and status anxiety: an interpretative phenomenological analysis of management consultants. Organization, $O(0): 1-20$.

Greenwood, R., Hinings, C. R., \& Brown, J. (1990). "P2-Form" Strategic Management: Corporate Practices in Professional Partnership. Academy of Management Journal, 33(4): 725-755.

Handel, W. (1979). Normative expectations and the emergence of meaning as solutions to problems: convergence of structural and interactionist views American Journal of Sociology, 84(1): 855-881.

Hinings, C. R., Greenwood, R., \& Cooper, D. (1999). The dynamics of change in large accounting firms. In D. M. Brock, C. R. Hinings \& M. J. Powell (Eds.), Restructuring the Professional Organization: Accounting, Health Care and Law: Routledge.

Ibarra, H. (1999). Provisional selves: Experimenting with image and identity in professional adaptation. Administrative Science Quarterly, 44(4): 764-791.

Kärreman, D., \& Alvesson, M. (2004). Cages in Tandem: Management Control, Social Identity, and Identification in a Knowledge-Intensive Firm. Organization, 11(1): 149175.

Kärreman, D., \& Alvesson, M. (2009). Resisting resistance: Counter-resistance, consent and compliance in a consultancy firm. Human Relations, 62(8): 1115-1144.

Katz, R., Tushman, M., \& Allen, T. . (1995). Dual ladder promotions in R\&D. Management Science, 41(848-863).

Kipping, M., \& Kirkpatrick, I. (2012). Alternative Pathways of Change in Professional Services Firms: The Case of Management Consulting. Journal of Management Studies.

Kitay, J., \& Wright, C. (2002). 'But does it work?' Perceptions of the impact of management consulting. Strategic Change, 11(5): 271-278.

Kosmala, K., \& Herrbach, O. (2006). The ambivalence of professional identity : On cynicism and jouissance in audit firms. Human Relations, 59(10): 1393-1428.

Kunda, G. (1992). Engineering Culture: Control And Commitment in a High-tech Corporation. Philadelphia: Temple University Press. 
Legge, K. . (2002). On Knowledge, Business Consultants and the Selling of Total Quality Management. In R. Fincham \& T. Clark (Eds.), Critical Consulting: New Perspectives on the Management Advice Industry: Blackwell Publishers.

Løwendahl, B.R., Revang, O., \& Fosstenløkken, S. (2001). Knowledge and Value Creation in Professional Service Firms - A Framework for Understanding and Analysis. Human Relations, 54(7): 911-931.

Lynch, K.D. (2007). Modeling Role Enactment: Linking Role Theory and Social Cognition. Journal for the Theory of Social Behaviour, 37(4): 279-399.

Maister, D.H. (1993). Managing the professional service firm. New York: Free Press Paperbacks.

Malhotra, N., \& Morris, T. (2009). Heterogeneity in professional service firms. Journal of Management Studies, 46(6): 895-922.

Malhotra, N., Morris, T., \& Hinings, C. R. (2006). Variation in Organizational Form among Professional Service Organizations. Research in the Sociology of Organizations, 24 : 171-202.

Matthews, D. (2006). A History of Auditing: The Changing Audit Process In Britain Since 1800: Routledge.

Mazmanian, M., Orlikowski, W., \& Yates, J. (2011). The Autonomy Paradox: The Implications of Mobile Email Devices for Knowledge Professionals. Organization Science, Articles in advance: 1-21.

McKenna, C.D. (2006). The World's Newest Profession: Management Consulting in the Twentieth Century. New York: Cambridge University Press.

Meriläinen, S., Tiernari, J., Thomas, R., \& Davies, A. . (2004). Management Consultant Talk: A Cross-Cultural Comparison of Normalizing Discourse and Resistance Organization, 11(4): 539-564.

Michel, A. . (2011). Transcending Socialization: A Nine-Year Ethnography of the Body's Role in Organizational Control and Knowledge Workers' Transformation. Administrative Science Quarterly, 56(3): 325-368.

Mintzberg, H. (1989). Mintzberg on Management: Inside our Strange World of Organizations: Free Press.

Morris, T. (2001). Asserting property rights: Knowledge codification in the professional service firm. Human Relations, 54(7): 819-838. 
Morris, T., \& Empson, L. (1998). Organisation and expertise: An exploration of knowledge bases and the management of accounting and consulting firms. Accounting, Organizations and Society, 23(5-6): 609-624.

Muhr, S.L., Pedersen, M. , \& Alvesson, M. (2013). Workload, Aspiration, and Fun: Problems of Balancing Self-Exploitation and Self-Exploration in Work Life. In M. Holmqvist \& A. Spicer (Eds.), Managing 'Human Resources' by Exploiting and Exploring People's Potentials (Vol. 37: pp. 193-220): Emerald Group Publishing Limited.

Pedersen, M. (2008). Tune in, break down, and reboot : New machines for coping with the stress of commitment. Culture and Organization, 14(2): 171-185.

Perlow, L. (2012). Sleeping with your Smartphone: How to Break the 24/7 Habit and Change the Way you Work. Boston, Massachusetts: Harvard Business Review Press.

Poulter, D., \& Land, C. (2008). Preparing to work: dramaturgy, cynicism and normative 'remote' control in the socialization of graduate recruits in management consulting. Culture and Organization, 14(1): 65-78.

Powell, M.J., Brock, D.M., \& Hinings, C. R. (1999). The changing professional organization. In D. M. Brock, M. J. Powell \& C. R. Hinings (Eds.), Restructuring the professional organization. New York: Routledge.

Pratt, M.G., Rockmann, K.W., \& Kaufmann, J.B. (2006). Constructing Professional Identity: The Role of Work and Identity Learning Cycles in the Customization of Identity among Medical Residents. Academy of Management Journal, 49(2): 325-262.

Sardas, JC. (2008). La "Dynamique identitaire Globale" comme analyseur de risques de non performance et des risques psychosociaux Prévention du stress et des risques psychosociaux au travail: Editions Anact.

Sardas, JC., Dalmasso, C., \& Lefebvre, P. (2011). Les Enjeux Psychosociaux de la Santé au Travail: des modèles d'analyse à l'action sur l'organisation. Revue Française de Gestion(214): 69-88.

Sardas, JC., \& Gand, S. (2011). Les transitions professionnelles contraintes par des restructurations: dynamiques individuelles et modalités d'accompagnement. Gérer et Comprendre, 103(Mars 2011): 26-37.

Simpson, B. , \& Carroll, B. (2008). Re-viewing 'Role' in Processes of Identity Construction. Organization, 15(1): 29-50.

Starbuck, W.H. (1992). Learning by Knowledge-Intensive Firms. Journal of Management Studies, 29(6): 713-740. 
Strauss, A. (1978). Negotiations: Varieties, Contexts, Processes and Social Order. San Francisco CA: Jossey-Bass, Inc.

Strauss, A., Schatzman, L., Ehrlich, D., \& Bucher, M.S. . (1963). The hospital and its negotiated order. In E. Friedson (Ed.), The hospital in Modern Society. New York: Free Press of Glencoe.

Stumpf, S.A., Doh, J.P., \& Clark, K.D. (2002). Professional Services Firms in Transition: Challenges and Opportunities for Improving Performance. Organizational Dynamics, 31(3): 259-279.

Sturdy, A. (1997). The Consultancy Process - An Insecure Business. Journal of Management Studies, 34(3): 389-413.

Sturdy, A. (2012). The Future Research Agenda. In M. Kipping \& T. Clark (Eds.), The Oxford Handbook of Management Consulting. New York: Oxford University Press.

Sveningsson, S., \& Alvesson, M. (2003). Managing Managerial Identities: Organizational Fragmentation, Discourse and Identity Struggle. Human Relations, 56(10): 11631193.

Swart, J., \& Kinnie, N. (2003). Sharing knowledge in knowledge-intensive firms. Human Resource Management Journal, 13(2): 60-75.

Von Nordenflycht, A. (2010). What is a professional service firm? Toward a theory and taxonomy of knowledge-intensive firms. Academy of Management Review, 35(1).

Watson, T.J. (2008). Managing Identity: Identity Work, Personal Predicaments and Structural Circumstances. Organization, 15(1): 121-143.

Werr, A. (2002). The Internal Creation of Consulting Knowledge: A Question of Structuring Experience. In M. Kipping \& L. Engwall (Eds.), Management Consulting: Emergence and Dynamics of a Knowledge Industry. New York: Oxford University Press.

Werr, A., \& Stjernberg, T. (2003). Exploring Management Consulting Firms as Knowledge Systems. Organization Studies, 24(6): 881-908.

Werr, A., Stjernberg, T., \& Docherty, P. (1997). The functions of methods of change in management consulting. Journal of Organizational Change Management, 10(4): 288-307.

Yin, R.K. (2009). Case Study Research: Design and Methods (Fourth Edition ed.). USA: Sage. 